\title{
Influence of Price and Distributive Fairness on Micro Finance Customers' Relationship Commitment: PLS-SEM Analysis
}

\author{
Dr. Shaikh Rafiqul Islam ${ }^{\# 1}$ \\ ${ }^{\#}$ Professor, Department of Marketing, Jagannath University, Bangladesh
}

\begin{abstract}
Bangladeshi Micro Finance Institution (MFI) sector is highly competitive in financial industry. Due to strong multifaceted competition customer drop out (exit/switching) is taking place. In fact, to achieve sustainability, MFIs need to reduce the dropout rate and to retain customer by developing relationship commitment $(R C)$. Hence, the aim of the empirical study is to find out how the clients drop out from the MFI can be prevented through developing relationship commitment in the relational exchange context. The study focuses on the price fairness and distributive fairness as an antecedent of relationship commitment. The PLS-SEM technique is utilized for the analysis of data collected from 409 consumers of different MFI's of Bangladesh. The study employed survey method for getting responses from MFI consumers about price fairness, distributive fairness and relationship commitment related statement. The study explores that price fairness, distributive fairness, has significant effect on relationship commitment. Hence, the findings of this model may be applied by the policy makers and the practitioners as an approach to enhance relationship commitment in the MFI's in developing economy context.
\end{abstract}

Keywords-Price fairness, Distributive fairness, Relationship commitment, Relational exchange, MFI.

\section{INTRODUCTION}

The relationship marketing (RM) literature has long recognized that relationship commitment (RC) as the core concept of nurturing long-term relational exchange in competitive services offerings (Tse,Wang, \& Zhang, 2019; Climis, 2016; Shaikh, Karjaluoto, \& Chinje, 2015). The highest level of relationship attachment between exchange partners is represented by relationship commitment, which entails exchange partners' interdependency on each other and that "customer loyalty is achieved" (Dwyer et al., 1987). Scholars argued RC is shown to lead to customer loyalty and be affected by service fairness (Giovanis et al., 2015; Nikbin et al., 2014). However, previous studies have indicated the link between fairness and relationship commitment in commercial exchange, restaurant, banking (Matute-Vallejo et al., 2011; Namkung \& Jang, 2010) context of western world but neglected to consider the effect of fairness on RC in Micro Finance Institution (MFI) in the eastern world and Bangladesh in particular. This is surprising given the important role of MFIs in the development agenda where consumer confidence in the MFI industry has been bruised over the last few years. It is notwithstanding that, three quarter of customer drop outs in Bangladeshi MFI's happens willingly due to dissatisfaction with present service and a belief of getting better service from other MFI (Islam, 2016). Hence, to achieve sustainability, MFIs need to reduce the dropout rate by repeating its loan program to clients until they graduate from loan program. Already, scholars in MFI pointed out that that high quality symbiotic relationship with the clients is the most important asset of the MFIs rather than their loan portfolios (Counts, 2008) to build relationship commitment and retain them. In the same vein RM has been advocated as an excellent way to ascertain customer commitment (Jayashankar \& Goedegebuure, 2011). Meanwhile, different literatures in Bangladeshi MFI revealed poor fairness conditions: high interest rate on loan but low on savings, erosion of credit discipline, malpractice in maintaining loan account, are prevalent in offering services (Islam \& Natori, 2014; Rahman et al., 2014; Augsburg \& Fouillet, 2013).

Specifically, maintaining price and distributive fairness in building long term MFI- customer relationship is largely overlooked in the context of Bangladeshi MFI. Moreover, less focus has been given to know RC considering the relational exchange context whereas the financial institutions have considered service fairness is at the core of service delivery to establish a long term relationship of their business and marketing activities (Rizan et al., 2014). However, searching for solutions to rebuild trust and maintain clients' commitment is a critical task not only for MFI managers, but also for management and marketing research. On the other hand, few previous studies have analysed fairness in a general context validating the impact of service fairness on one of the individual components of relationship quality. But, there are dearth of previous studies investigating the 
impact of price fairness (PF) and distributive fairness (DF) on relationship commitment, conceptualized as higher order construct. To fill this gap in the literature, this paper focuses on analysing how price fairness and distributive fairness determine relationship commitment in the MFI sector.

\section{LITERATURE REVIEW}

\subsection{Relationship Commitment}

Empirical evidence in relationship marketing reveals that relationship commitment is deeply rooted in it. RM literature refers $\mathrm{RC}$ as the exchange partners desire and motivation to maintain valued relationship (Brun et al., 2016). The RC paradigm draws the conceptualization to explain customer organization relationship formation by adopting social psychology, marriage (interpersonal relationship) and organizational science stream (Giovanis, 2016; Ou et al., 2014; Tsai, 2011). Early research on commitment mainly focused on the employee commitment toward the organization (Xiao et al., 2010; Allen \& Meyer, 1990). Then after, the construct commitment is increasingly used in consumer research to analyze consumer behavior (Shukla et al., 2016). Moreover, some scholars also describe commitment as a relational construct which creates psychological bonds between exchanges partners from the purview of relationship commitment (Xiao et al., 2010). Relationship dedication has been viewed as "a drive which refers to different fundamental psychological states that mirror the nature of the person relationship with the target of interest and that have implication for the decision to continue that relationship" (Meyer et al., 1997). This psychological condition of RC is generally conceptualized as a multi-dimensional of three distinguishable components such as: affective commitment, continuance commitment, and normative commitment. This three dimensional approach of RC is a suitable platform for examining the emotional (affective), functional (calculative) and social (normative) aspect that reflect relationship commitment to MFI. Affective commitment reflects the consumers' emotional link to identification with and attachment in an organization (Meyer \& Smith, 2000). The second dimension, calculative commitment refers as the constraint based factor which bind the customer with service provider due to need. In this constraint based relationship, customer have the firm believe that they cannot cease the relationship due to economic, psychological or social costs (Bansal et al., 2004). Finally, normative commitment reflected as behaviors resulting from a sense of obligation (Brun et al., 2014). It is rooted in perception of reciprocal obligation that exchange partner feels for it relational partner (Meyer \& Parfyonova, 2010). Further, this approach to RC is also complementary to related concept of customer loyalty, brand loyalty and customer relationship management (Shukla et al. 2015).Moreover, there is general agreement that these three components of RC are employed by different marketing scholars (Fullerton, 2003;Harrison-Walker, 2001;Gruen et al., 2000) from the organizational behavior discipline to relationship marketing discipline. Hence, the multidimensional RC is measured as reflective second order construct considered as the most appropriate way of modeling and interpreting RC.

\subsection{Fairness}

The concept fairness is an evaluative judgment of consumer about the appropriate treatment they got from others (Adams, 1965; Blau, 1964). It is perceived as a basic criterion to judge the quality of human relationship and business success can be attainable by enhancing fairness perception in consumers mind (Clemmer \& Schneider, 1996). Consumers consider fairness in assessing commitment and overall return intentions to goods or services (Giovanis et al., 2015; Ting, 2011). In the context of service, fairness refers as a consumer's perception of the degree of justice in a service provider's behavior (Seiders \& Berry, 1998). However, consumers' evaluation of service fairness come in front when their experience is compared according to their fairness standards and they identify themselves as being either fairly or unfairly treated (Seiders \& Berry, 1998). Subsequently, this perception of fairness influences consumer attitude to build long term relationship (Giovains et al., 2015). For decades, extensive research on marketing and organization split the fairness in to three dimensions: distributive fairness, procedural fairness and interactional fairness of (Martíneztur et al., 2006). In marketing, most of the previous studies which reconstruct the fairness dimension mainly focused on service failure and recovery process (Mattila \& Cranage, 2005). However, service fairness dimension not only perceived from service recovery or failure perspective but also service fairness dimension can be viewed from context-dependent. Conceptualizing the later view Namkung et al. (2009) introduced a four factor of fairness (price fairness, distributive fairness, procedural fairness, and interactional fairness) construct which is also supported by Narteh (2016) and Nikbin et al. (2013) from the service delivery context. Authors' empirical research on fairness issues in the restaurant industry in USA confirmed the superior projective power of the four-factor model over the three-factor model. Further, they also recommended other researcher to validate the four-factor model in different research contexts. Briefly, price fairness refers as a consumer's perception, associated with emotion, about the rationality or justification of variation between seller's price and competitor's price (Xia et al., 2004). Distributive fairness refers as an assessment of fairness of the outcome 
received (Duffy et al., 2003). Procedural fairness refers to the policies and procedures employed by the service provider in producing the outcome (Giovanis et al., 2015). Finally, interactional fairness refers to the interpersonal treatment consumer receive in a service context (Blodgett et al., 1997). Moreover, previous studies also interpret these fairness dimensions as an individual construct (Narteh, 2016). Based on the above discussion, the present study considers PF and DF to examine the projective power of the model in MFI industry to assess whether customers' perception of price and distributive fairness impacts on their relationship commitment. Previous studies have identified a significant relationship between fairness and relationship commitment in various context (Giovanis et al., 2015; Ting, 2011; Yen \& Chu, 2009). Giovanis et al. (2015) suggested that service fairness positively affect relationship quality (satisfaction, trust and commitment). Specifically authors argue that customers' commitment increases due to fair treatments and they stay with the same service provider for longer periods. Moreover, Ting (2011) argued that individual dimensions of fairness affect customers' commitment to the relationship (distributive fairness, procedural fairness and interactional fairness) with service provider.

In most of the fairness studies indicates the perception of price fairness has a positive influence on relationship commitment (Namkung \& Jang, 2010; Matute-Vallejo et al., 2011).While, Namkung and Jang (2010) and Bei and Chiao, (2001) found that price fairness has a positive and significant effect on repatronage intention, a variable closely related to customer commitment (Ivens, 2005). Moreover the authors indicates the significance of price fairness to establish pricing strategies for successful business because consumer may evaluate the economic acceptability of the price level in relation to their own interest and at the same time keep in their cognizance about the social acceptability of the price in relation to community standards or rules. Again, Matute-Vallejo et al. (2011) investigated the influence of price fairness on customer commitment in Spanish retail banking context and found that price fairness has positive and significant influence on customer commitment to retail banking.

Moreover, previous researches had been conducted on the influence of distributive fairness to predict relationship commitment and found a positive relationship between distributive fairness and relationship commitment (Bahri-Ammari \& Bilgihan, 2017; Choi, 2016; Nikbin et al., 2014; Aurier \& Siadou-Martin, 2007). In short, exchange partners perception of higher distributive fairness strengthens their incentives to increase commitment (Choi, 2016). For instances, in B2B context Choi (2016) has examined the influence of exporter fairness on importers commitment. The result of the study indicates positive relationship between exporter fairness and importers commitment.

However, the aforesaid studies focused on the relationship between fairness perception and relationship commitment. A good number of studies have investigated the link between fairness and commitment is justified (Manshor et al., 2016; Giovanis et al., 2015; Nikbin et al., 2013; Yen \& Chu, 2009). While, most of the studies related to fairness perception have been focused on the different service settings such as banking industry, auto repair, tourism, airline and organizational context whereas fairness and relationship commitment in micro finance institution was ignored. Till now, a few studies have found the direct relationships between four factor fairness (price fairness, distributive fairness, procedural fairness and interactional fairness) and behavioral intention not directly relationship commitment (Narteh, 2016; Nikbin et al., 2014; Chen et al., 2012; Namkung \& Jung, 2010). Further, there are some dearth of study related to fairness and relationship commitment in the field of MFI.

\subsection{Theoretical Framework}

Present study is based on the Relational Exchange Theory (RET) (Macneil, 1980), develop a unique governance mechanism in buyer-seller behaviour in exchange relationship (Macneil, 1980; Morgan \& Hunt, 1994). It is rooted in Macaulay's (1963) influential research on non-contractual business relationships. RET also conceptualized that fairness is encompasses in all facet of relational exchange (Macneil, 1985). It has been regarded as important in relational exchange (Devlin et al., 2014; Kumar et al., 1995). In the relational exchange context customer perception of fairness in sellers activity leads to commitment to the relationship but perception of unfairness may influence customer to terminate the relationship (Giovains et al., 2015; N'Goala, 2007; Dwyer et al., 1987; Scanzoni, 1979).

The relationship therefore describes the association between the independent variables and the dependent variable. Thus the framework draws a suitable model to investigate how price and distributive fairness influence customers' relationship commitment. 


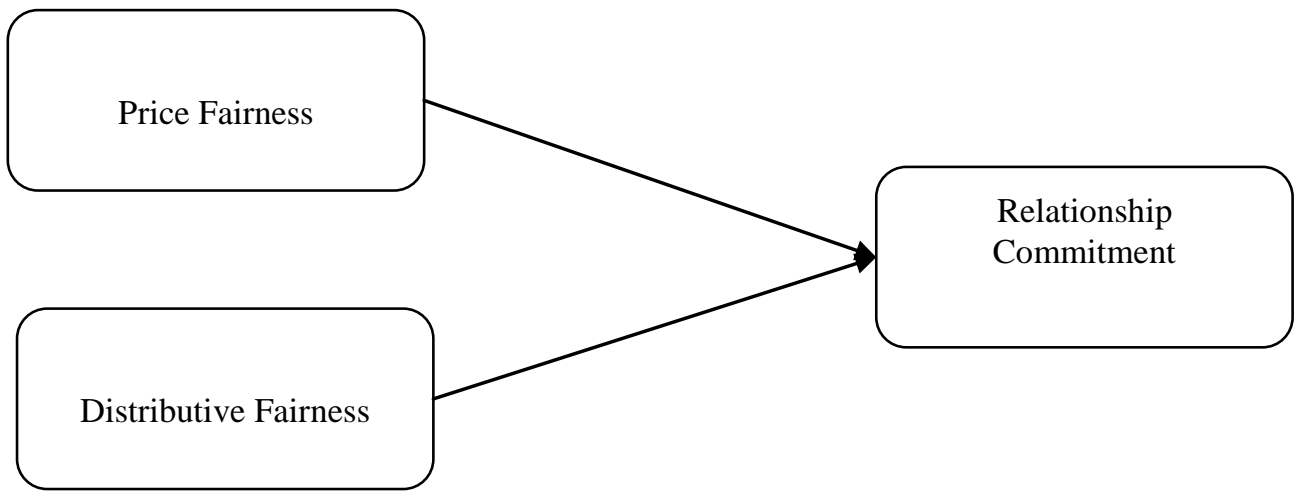

Figure 1: Framework of the hypothesized model

\subsubsection{Hypotheses of the Study}

Based on the above discussion the study is conducted to test the following hypothesis:

H1: Price fairness positively affects the relationship commitment in MFI.

H2: Distributive fairness positively affects the relationship commitment in MFI.

\section{III.METHODOLOGY}

The study applied systematic sampling technique to determine the sample size, which is one of the basic categories of probability sampling (Sekaran \& Bougie, 2010; Cooper \& Schindler, 2006), on the clients of MFI in the Dhaka division in Bangladesh. Data were collected from 538 clients of MFI's in six districts of Dhaka division. Consequently, out of 538 distributed questionnaires a total number of 457 respondents, from six districts of Dhaka divisions of Bangladesh, filled and returned there response. This accounted for 85 percent response rate in accordance with Jobber's(1989) conceptualization of response rate. However, we discarded a total of 48 questionnaires due to missing data and multivariate outliers leaving 409 effective responses which is 76 percent of distributed questionnaires, suggesting more than adequate by the scholars (Hair et al., 2010). Measures were taken from different research scholars previous studies and adapted to suit the MFI context. In this study, constructs price fairness, distributive fairness were measured by adapting indicators suggested by Narteh, 2016; F.Devlin et al., 2014 respectively. Meanwhile, RC constructs (affective, calculative and normative) were adapted from (Izogo, 2017; Shukla et al., 2016; Fullerton, 2014) respectively. All items were measured on five-point Likert scales anchored at 1(strongly disagree) and 5(strongly agree) that was valid and appropriate measurement as many earlier studies have implemented it successfully (Narteh et al., 2013). The total numbers of items were 26 where 21 items were related to fairness and relationship commitment, and remaining 5 items have been developed with demographic information of the respondents. The study applied partial least squares (PLS)technique an implementation of structural equation modeling (SEM) with Smart PLS 3.2.7(Ringle et al., 2017) to examine conceptual model and test the proposed hypotheses.

\section{IV.PRESENTATION AND ANALYSIS OF RESULTS}

\subsection{Measurement Model Assessment}

The measurement model deals with the measurement of latent variables of the PLS-SEM path modeling. Each latent construct of the model comprises with reflective multiple observation. Assessment of measurement model includes the estimation individual item reliability, internal consistency reliability, content validity, convergent validity and discriminant validity (Hair et al., 2016). Figure: 2 illustrates the measurement model. After initial run of PLS-SEM, some items showed factor loading less than 0.70 (one item from distributive fairness scale) and for that reason were deleted. 


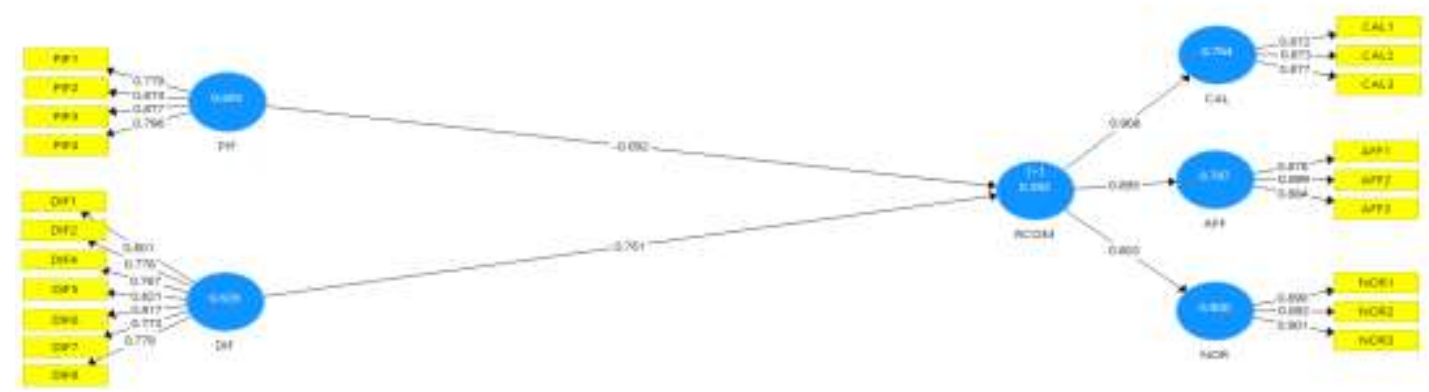

Figure 2: Measurement model

The factor loadings of the non-deleted items showed in Table 1. Cronbach's alpha coefficient range between 0.846 and 0.913 while composite reliability (CR) coefficients range between 0.900 and 0.929 exceeding the threshold of 0.70 (Nunnally, 1978), indicated adequate internal consistency reliability of the construct. Convergent validity of the items was assessed by the approaches developed by Fornell and Larcker (1981) for PLS. Consequently, the AVE of each latent construct was above 0.5 indicating adequate convergent validity of the constructs.

Table 1 Item Loading, Internal Consistency, average variance extracted

\begin{tabular}{|c|c|c|c|c|c|c|}
\hline Construct /Dimension & $\begin{array}{c}\text { Higher Order } \\
\text { Construct }\end{array}$ & Item & Loading & $\begin{array}{c}\text { Cronbach's } \\
\text { Alpha }\end{array}$ & $\mathbf{C R}$ & AVE \\
\hline \multirow[t]{3}{*}{ Affective Commitment } & & AFF1 & 0.878 & & & \\
\hline & & AFF2 & 0.899 & 0.865 & 0.917 & 0.787 \\
\hline & & AFF3 & 0.884 & & & \\
\hline \multirow[t]{3}{*}{ Calculative Commitment } & & CAL1 & 0.872 & & & \\
\hline & & CAL2 & 0.873 & 0.846 & 0.907 & 0.764 \\
\hline & & CAL3 & 0.877 & & & \\
\hline \multirow[t]{4}{*}{ Normative Commitment } & & NOR1 & 0.890 & & & \\
\hline & & NOR2 & 0.892 & 0.875 & 0.923 & 0.800 \\
\hline & & NOR3 & 0.901 & & & \\
\hline & RCOM & & & 0.913 & 0.929 & 0.592 \\
\hline \multirow[t]{7}{*}{ Distributive Fairness } & & DIF1 & 0.801 & & & \\
\hline & & DIF2 & 0.778 & & & \\
\hline & & DIF4 & 0.767 & & & \\
\hline & & DIF5 & 0.821 & 0.900 & 0.921 & 0.626 \\
\hline & & DIF6 & 0.817 & & & \\
\hline & & DIF7 & 0.773 & & & \\
\hline & & DIF8 & 0.778 & & & \\
\hline \multirow[t]{4}{*}{ Price Fairness } & & PIF1 & 0.779 & & & \\
\hline & & PIF2 & 0.874 & 0.858 & 0.900 & 0.693 \\
\hline & & PIF3 & 0.877 & & & \\
\hline & & PIF4 & 0.796 & & & \\
\hline
\end{tabular}

Discriminant validity refers as the extent to which the every construct of the model is different from each other (Hair et al., 2016). Fornell and Larcker (1981) criterion was used to test the discriminant validity of the constructs. Table 2 showed the square root of AVE of each construct in the matrix (bold face) were all above the correlations among latent variables (off diagonal), suggesting adequate discriminant validity (Fornell \& Larcker, 1981), and suggesting adequate discriminant validity. 
Table 2 Latent variables correlations and square roots of average variance extracted

\begin{tabular}{|c|c|c|c|c|c|}
\hline & AFF & CAL & DIF & NOR & PIF \\
\hline AFF & $\mathbf{0 . 8 8 7}$ & & & & \\
\hline CAL & 0.761 & $\mathbf{0 . 8 7 4}$ & & & \\
\hline DIF & 0.763 & 0.718 & $\mathbf{0 . 7 9 1}$ & & \\
\hline NOR & 0.548 & 0.591 & 0.518 & $\mathbf{0 . 8 9 4}$ & \\
\hline PIF & -0.178 & -0.222 & -0.125 & -0.079 & $\mathbf{0 . 8 3 3}$ \\
\hline
\end{tabular}

Moreover, another recent method to assess discriminant validity is heterotrait-monotrait (HTMT) ratio of correlations (Henseler et al., 2015) which considered as more conservative and better assess the discriminant validity more reliability than other approaches. Table 3 indicated that the entire latent construct has successfully passed the HTMT0.90 criterion (Henseler et al., 2015), thereby, indicating that discriminant validity is not an issue in the present study.

Table 3 Heterotrait-monotrait (HTMT)

\begin{tabular}{|c|c|c|c|c|}
\hline & AFF & CAL & DIF & NOR \\
\hline CAL & 0.886 & & & \\
\hline DIF & 0.857 & 0.815 & & \\
\hline NOR & 0.629 & 0.685 & 0.578 & \\
\hline PIF & 0.185 & 0.251 & 0.137 & 0.084 \\
\hline
\end{tabular}

\subsection{Structural Model Assessment}

The present study assesses the structural model by applying PLS-SEM bootstrapping resample procedure. This method was also used to confirm the hypothesized relationships between latent constructs in the proposed model. In addition to that this study tested the mediation effect by PLS approach in which significance of the relevant path coefficients was evaluated via bootstrap.

Table 4 Structural model assessment

\begin{tabular}{|c|c|c|c|c|c|c|}
\hline No. & Hypotheses path & $\begin{array}{c}\text { Path } \\
\text { Coefficients }\end{array}$ & $\begin{array}{c}\text { Standard } \\
\text { Error }\end{array}$ & $\mathbf{T}$ value & P Value & Decision \\
\hline 1. & PIF -> RCOM & -0.092 & 0.03 & 3.1 & $0.001 * * *$ & Supported \\
\hline 2. & DIF-> RCOM & 0.761 & 0.039 & 19.436 & $0.000 * * *$ & Supported \\
\hline
\end{tabular}

The path model (Figure 3) measure the T-value between the constructs and related indicators of the particular latent construct. Hence, structural model signifies the level of the constructs as well as the manifest constructs. Results depicted in Table 4 and Figure 3 show that the hypothesized significant positive relationships between price fairness and relationship commitment $(\beta=-0.092, \mathrm{t}=3.1, \mathrm{p}<0.001)$, distributive fairness and relationship commitment $(\beta=0.761, \mathrm{t}=19.436, \mathrm{p}<0.001)$. The present study assessed the $\mathrm{R}^{2}$ (coefficients of determination) values for relationship commitment and happiness 0.747 and 0.695 respectively. This study considers the variance as acceptable (Chin, 1998).

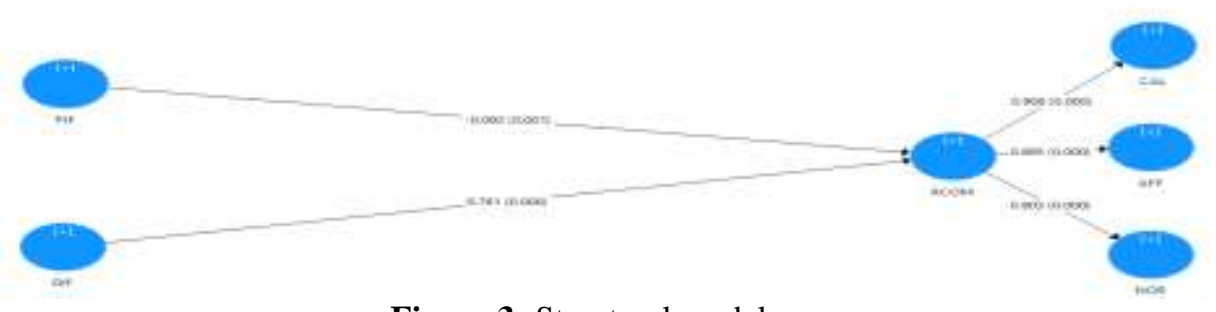

Figure 3: Structural model 


\section{DISCUSSION OF THE RESULTS}

The aim of this study was to validate the proposed research model for MFI sector. In particular, the aim was to investigate the direct effect of price and distributive fairness constructs on RC in MFI context. The present study's contribution is twofold. First, it uses the relational exchange constructs to develop a model and integrates relevant concepts into a structural model and tested empirically by using data collected from the MFI clients. Till to date few studies have considered PIF and DIF as antecedents of relationship commitment in an integrated model. Second, the results revealed significant direct relationship between fairness constructs and RC. However, the findings of this study have a number of significant implications for both academicians and practitioners. From an academic point of views, the findings corroborate with the findings of the previous studies showing that price fairness, distributive fairness, has the effect on RC (Nikbin et al., 2013; Giovanis et al., 2015). These reinforce the idea that the importance of perceived fairness on forming $\mathrm{RC}$ in the context of MFI cannot be overlooked. As depicted in the findings, MFI consumers will be more willing to maintain relationship with MFI that are perceived as offering fair interest rate on deposit and loan, fair transaction charge. Further, the results have suggested that keeping promise, fair loan condition and recovery procedure, friendly service and bias free maintenance of loan account are also important for customer to form RC with MFI. This shows that perception of fairness increase relationship commitment. Therefore, service provider should provide fair service to all of their customers whether they have the relationship with them or not. Furthermore, this study contributes to theory by empirically validating the role of fairness as relational exchanges construct that gained scanty research attention. Finally, the results become more important if we consider that relationship commitment is a mechanism by which organization leads to enhance financial performance and earnings. MFI management should strive to be perceived as fair in their price, distributive policy that induce customer to maintain long term relationship. Therefore, it is crucial for MFI management to better understand the interactions and dynamics of the antecedents of relationship commitment in order to gain competitive advantage.

\section{VI.CONCLUSION}

The present study demonstrates that it will be the best for the MFIs to apply relational exchange approach in building commitment to the relationship which can prevent customer's drop out and encounter enormous challenges facing the sector. Finally, as far as future research concerned, this proposed research framework may be used for further research on other context to generalize the findings.

\section{REFERENCES}

[1] Adams, J. S. (1965). Inequity in social exchange. Advances in Experimental Social Psychology, 2, 267-299.

[2] Augsburg, B., \& Fouillet, C. (2013). Profit empowerment: The microfinance institution's mission drift. Studies of Impact and Performance: The Credibility of Microcredit, 9, 327-355.

[3] Aurier, P., \& Siadou-Martin, B. (2007). Perceived justice and consumption experience evaluations: a qualitative and experimental investigation. International Journal of Service Industry Management, 18(5), 450-471.

[4] Bahri-Ammari, N., \& Bilgihan, A. (2017). The effects of distributive, procedural, and interactional justice on customer retention: An empirical investigation in the mobile telecom industry in Tunisia. Journal of Retailing and Consumer Services, 37, 89-100.

[5] Bansal, H. S., Irving, P. G., \& Taylor, S. F. (2004). A three-component model of customer to service providers. Journal of the Academy of Marketing Science, 32(3), 234-250.

[6] Bei, L. T., \& Chiao, Y. C. (2001). An integrated model for the effects of perceived product, perceived service quality, and perceived price fairness on consumer satisfaction and loyalty. Journal of Consumer Satisfaction, Dissatisfaction and Complaining Behavior,

[7] Blau, P. M. (1964). Exchange and power in social life. New York: John Wiley \& Sons, Inc.

[8] Brun, I., Rajaobelina, L., \& Ricard, L. (2016). Online relationship quality: Testing an integrative and comprehensive model in the banking industry. Journal of Relationship Marketing, 15(4), 219-246.

[9] Brun, I., Rajaobelina, L., \& Ricard, L. (2014). Online relationship quality: Scale development and initial testing. International Journal of Bank Marketing, 32(1), 5-27.

[10] Chen, H. G., Yu-Chih Liu, J., Shin Sheu, T., \& Yang, M. H. (2012). The impact of financial services quality and fairness on customer satisfaction. Managing Service Quality: An International Journal, 22(4), 399-421.

[11] Choi, C. B. (2016). Overseas exporter fairness and Korean importer's commitment. Journal of Korea Trade, 20(2), 186-198.

[12] Clemmer, E. C., \& Schneider, B. (1996). Fair service. In A. Teresa , Swartz, E. David, Bowen, and W.Stephen, Brown (Ed.), Advances in services marketing and management (pp.109-126). Greenwich, CT: JAI Press.

[13] Climis, R. (2016). Factors affecting customer retention in the airline industry. Journal of Management and Business Administration, 24(4), 49-69. 
[14] Counts, A. (2008). Reimagining microfinance. Stanford Social Innovation Review, 8(1), 45-53.

[15] Devlin, J. F., Roy, S. K., \& Sekhon, H. (2014). Perceptions of fair treatment in financial services: Development, validation and application of a fairness measurement scale. European Journal of Marketing, 48(7-8), 1315-1332.

[16] Duffy, R., Fearne, A., \& Hornibrook, S. (2003). Measuring distributive and procedural justice: An exploratory investigation of the fairness of retailer-supplier relationships in the UK food industry. British Food Journal, 105(10), 682-694.

[17] Dwyer, F. R., Schurr, P. H., \& Oh, S. (1987). Developing buyer-seller relationships. Journal of marketing, 51(2), 11-27.

[18] Fornell, C., \& Larcker, D. F. (1981). Structural equation models with unobservable variables and measurement error: Algebra and statistics. Journal of Marketing Research, 18(3). 382-388.

[19] Fullerton, G. (2014). The moderating effect of normative commitment on the service quality-customer retention relationship. European Journal of Marketing, 48(3/4), 657-673.

[20] Giovanis, A. (2016). Consumer-brand relationships' development in the mobile internet market: Evidence from an extended relationship commitment paradigm. Journal of Product \& Brand Management, 25(6), 568-585.

[21] Giovanis, A., Athanasopoulou, P., \& Tsoukatos, E. (2015). The role of service fairness in the service quality-relationship qualitycustomer loyalty chain: An empirical study. Journal of Service Theory and Practice, 25(6), 744-776.

[22] Gruen, T. W., Summers, J. O., \& Acito, F. (2000). Relationship marketing activities, commitment, and membership behaviors in professional associations. Journal of Marketing, 64(3), 34-49.

[23] Hair, J.F., Hult, G.T.M., Ringle, C.,Sarstedt, M. (2016). A Primer on partial least squares structural equation modeling (PLS-SEM) (2nd ed.). USA: Sage Publications

[24] Harrison-Walker, L. J. (2001). The measurement of word-of-mouth communication and an investigation of service quality and customer commitment as potential antecedents. Journal of Service Research, 4(1), 60-75.

[25] Henseler, J., Ringle, C. M., \& Sarstedt, M. (2015). A new criterion for assessing discriminant validity in variance-based structural equation modeling. Journal of the Academy of Marketing Science, 43(1), 115-135.

[26] Islam, T. (2016). Microcredit and poverty alleviation. Routledge.

[27] Islam, M. T., \& Natori, T. (2014). An assessment of customer satisfaction in microfinance in Bangladesh. International Journal of Business and Systems Research, 8(1), 91-109.

[28] Ivens, B. S. (2005). Flexibility in industrial service relationships: The construct, antecedents, and performance outcomes. Industrial Marketing Management, 34(6), 566-576.

[29] Izogo, E. E. (2017). Customer loyalty in telecom service sector: The role of service quality and customer commitment. The TQM Journal, 29(1), 19-36.

[30] Jayashankar, P., \& Goedegebuure, R. V. (2011). Marketing Strategies and Social Performance Outcomes: A field study on MFI clients. The IUP Journal of Marketing Management, 5(2), 7-32.

[31] Jobber, D. (1989). An examination of the effects of questionnaire factors on response to an industrial mail survey. International Journal of Research in Marketing, 6(2), 129-140.

[32] Kumar, N., Scheer, L. K., \& Steenkamp, J. B. E. (1995). The effects of supplier fairness on vulnerable resellers. Journal of Marketing Research, 32(1), 54-65.

[33] Macaulay, S. (1963). Non-contractual relations in business: A preliminary study. American Sociological Review, 28(1), 55-67.

[34] Macneil, I. R. (1980). The new social contract: An inquiry into modern contractual relations. USA: Yale University Press.

[35] Macneil, I. R. (1985). Relational contract: What we do and do not know. Wisconsins Law Review, 3, 483-526.

[36] Manshor, R., Muda, M. S., Salleh, A. M. M., Razak, F. Z. A., \& Kamaazura, A. B. (2016). Assessing the effects of organizational justice on organizational commitment in Malaysia's SME sector. Journal of Advanced Research in Business and Management Studies, 2(1), 64-73.

[37] Martínez-Tur, V., Peiró, J. M., Ramos, J., \& Moliner, C. (2006). Justice perceptions as predictors of customer satisfaction: The impact of distributive, procedural, and interactional justice. Journal of Applied Social Psychology, 36(1), 100-119.

[38] Mattila, A. S., \& Cranage, D. (2005). The impact of choice on fairness in the context of service recovery. Journal of Services Marketing, 19(5), 271-279.

[39] Matute-Vallejo, J., Bravo, R., \& Pina, J. M. (2011). The influence of corporate social responsibility and price fairness on customer behaviour: Evidence from the financial sector. Corporate Social Responsibility and Environmental Management, 18(6), 317-331.

[40] Meyer, J. P., \& Parfyonova, N. M. (2010). Normative commitment in the workplace: A theoretical analysis and re-conceptualization. Human Resource Management Review, 20(4), 283-294.

[41] Meyer, J. P., \& Smith, C. A. (2000). HRM practices and organizational commitment: Test of a mediation model. Canadian Journal of Administrative Sciences, 17(4), 319-331.

[42] Meyer, J. P., \& Allen, N. J. (1997). Commitment in the workplace: Theory, research, and application (Advanced topics in organizational behavior). Thousand Oaks, CA: Sage Publications.

[43] Morgan, R. M., \& Hunt, S. D. (1994). The commitment-trust theory of relationship marketing. The Journal of Marketing, 58(3), 20-38. 
[44] Namkung, Y., Jang, S., Almanza, B., \& Ismail, J. (2009). Identifying the underlying structure of perceived service fairness in restaurants. International Journal of Contemporary Hospitality Management, 21(4), 375-392.

[45] Narteh, B. (2016). Service fairness and customer behavioural intention: Evidence from the Ghanaian banking industry. African Journal of Economic and Management Studies, 7(1), 90-108.

[46] Narteh, B., Agbemabiese, G. C., Kodua, P., \& Braimah, M. (2013). Relationship marketing and customer loyalty: Evidence from the Ghanaian luxury hotel industry. Journal of Hospitality Marketing \& Management, 22(4), 407-436.

[47] N'Goala, G. (2007). Customer switching resistance (CSR): The effects of perceived equity, trust and relationship commitment. International Journal of Service Industry Management, 18(5), 510-533.

[48] Nikbin, D., Hyun, S. S., Iranmanesh, M., \& Foroughi, B. (2014). Effects of perceived justice for coaches on athletes' trust, commitment, and perceived performance: A study of futsal and volleyball players. International Journal of Sports Science \& Coaching, 9(4), 561-578.

[49] Nikbin, D., Marimuthu, M., \& Hyun, S. S. (2013). Influence of perceived service fairness on relationship quality and switching intention: An empirical study of restaurant experiences. Current Issues in Tourism, 19(10), 1005-1026.

[50] Nunnally, J. C. (1978). Psychometric Theory. New York: McGraw-Hill.

[51] Ou, W. M., Shih, C. M., \& Chen, C. Y. (2014). Antecedents and consequences of relationship commitment: An empirical study in Taiwan. International Journal of Commerce and Management, 24(3), 228-242.

[52] Rahman, M. K., Rahman, M. M., \& Jalil, M. A. (2014). Factor analysis of drop out clients in microfinance institutions (MFIs) in Satkhira district in Bangladesh. Review of European Studies, 6(2), 31-39.

[53] Ringle, C., Wende, S. and Becker, J.-M. (2017), SmartPLS-statistical software for structural equation modeling. Smartpls.com. 2017 [cited 2017 December 16]. Retrieved from: http://www.smartpls.com

[54] Rizan, M., Warokka, A., \& Listyawati, D. (2014). Relationship marketing and customer loyalty: Do customer satisfaction and customer trust really serve as intervening variables?. Journal of Marketing Research \& Case Studies, 2014(2014), 1-12.

[55] Scanzoni, J. (1979). Social exchange and behavioral interdependence. In R.L.Burgess \& T.L. Huston (Ed.), Social Exchange in Developing Relationships (pp. 61-98). NewYork: Academic Press.

[56] Seiders, K., \& Berry, L. L. (1998). Service fairness: What it is and why it matters?. The Academy of Management Executive, 12(2), 820.

[57] Shaikh, A. A., Karjaluoto, H., \& Chinje, N. B. (2015). Continuous mobile banking usage and relationship commitment-A multicountry assessment. Journal of Financial Services Marketing, 20(3), 208-219.

[58] Shukla, P., Banerjee, M., \& Singh, J. (2016). Customer commitment to luxury brands: Antecedents and consequences. Journal of Business Research, 69(1), 323-331.

[59] Ting, S. C. (2011). The role of justice in determining relationship quality. Journal of Relationship Marketing, 10(2), 57-75.

[60] Tsai, S. P. (2011). Strategic relationship management and service brand marketing. European Journal of Marketing, 45(7/8), 11941213.

[61] Tse, S. Y., Wang, D. T., \& Zhang, T. J. (2019). The effects of distributor relationship commitment and relationship exploration on opportunism: The moderating roles of exchange uncertainties and network factors. Industrial Marketing Management.

[62] Xia, L., Monroe, K. B., \& Cox, J. L. (2004). The price is unfair! A conceptual framework of price fairness perceptions. Journal of Marketing, 68(4), 1-15.

[63] Xiao, Y., Zheng, X., Pan, W., \& Xie, X. (2010). Trust, relationship commitment and cooperative performance: Supply chain management. Chinese Management Studies, 4(3), 231-243.

[64] Yen, T. F., \& Chu, K. K. (2009). Do more investments or higher justice win the higher loyalty?. International Journal of Electronic Business Management, 7(3).211-223. 